\title{
On the problem of development of built-up areas and improving quality of the urban environment (on the example of Ulan-Ude)
}

\author{
Galina Zharkaia ${ }^{1}$, Olga Osodoeva $^{1}$, Olga Sanzhina ${ }^{1}$, and Yuliana Gunazhinova ${ }^{1, *}$ \\ ${ }^{1}$ Eastern Siberian State University of Technologies and Management, 670013, Kluchevskaia srt., 40v, \\ Ulan-Ude, Russia
}

\begin{abstract}
The built-up areas in the cities have a trend towards developing slums due to excessive urbanization that leads to dividing city areas to useful and ineffective. The problem of large cities originates in ineffective property management, excessive losses from the maintenance and operation of buildings and structures. Considering this issue from the perspective of the effective use of territories, it is impossible not to refer to such a mechanism as development. It considers management and development through the integrated development and spatial planning with maximum benefit. Zoning of territories on profitable, low-income and unprofitable segments will allow elaborating projects focused on generating additional benefit by attracting private entrepreneurs and avoid losses in exploitation. In addition to that, it will allow analyzing prospective projects taking into account the existing urban development and formation of a comfortable urban environment for the population.
\end{abstract}

Nowadays, the urban development, especially as related to transformation of the territorial structure, has a substantial inertia, since the spatial order, levels of populating and development have been created for decades, and sometimes for centuries. On this reason, successful urban development should be based on the detailed consideration and utilization of the existing situation and its major transformation trends. In this connection the issue of management of the built-up areas takes a lead in about all cities. Now it is accepted to speak not about reconstruction and renovation of territories but about their development or investment and construction development [1].

Despite the fact that the term "development" is the English word meaning "broadening, expanding, growth, evolution, etc.", originally it is a widely used word. In Russia, the word "development" for a long time has been used in different contexts. Typically it means investment and construction or urban development of the territory, one of the peculiar directions of which is spatial planning. In the economic sense, development is an entrepreneurship connected with the development and management of real estate objects, change of qualitative indicators for expanding their value and improving functional

\footnotetext{
*Corresponding author: uin_07@mail.ru
} 
characteristics. There are different types of development depending on its functional orientation (Table 1).

Table 1 Classification of types of development in the global practice [2].

\begin{tabular}{|c|l|}
\hline Type of development & \multicolumn{1}{c|}{ Definition } \\
\hline Development & $\begin{array}{l}\text { Business activity focused on qualitative changes in a real estate } \\
\text { object providing increase of its value, and development of } \\
\text { measures for the management of an object. }\end{array}$ \\
\hline Redevelopment & $\begin{array}{l}\text { Activities aimed at improving functional characteristics of an } \\
\text { existing facility through reconstruction, modernization or major } \\
\text { repairs, or demolition of a building and construction of a new } \\
\text { one, for greater benefit. }\end{array}$ \\
\hline Land-development & $\begin{array}{l}\text { Investment activities aimed at efficient development of land } \\
\text { through the targeted use and increasing its value. }\end{array}$ \\
\hline
\end{tabular}

In current circumstances, the developers' activities are mostly focused on getting a speculative profit. However, there are some projects that are aimed at creation of social infrastructure and improving quality of the urban environment.

Competition for the improvement of the city waterfront that has taken place in Ulan-Ude is one of the examples of that. This competition has been open for all and conducted in the form of an open vote. Three projects, for which the residents of the city voted, have been selected as a result of this competition. Each of these projects is unique and focused on improving comfort and accomplishment of the city.

A special land area of 18.7 hectares has been allocated to the participants of the competition on the embankment of the rivers Uda and Selenga in the center of the city (Figure 1 ), in the situation of the built-up area (Figure 2). According to the specification, the basic requirements for the design project have been the following: to design complex architectural planning of the accomplishment of the territories of a public space, to form a common stylistic solution of the embankment territory, to consider measures on improvement of the transport and pedestrians schemes, and to make proposals on the optimal deployment of the planned and reconstructed objects of public and civil construction in the area of the embankment [3].

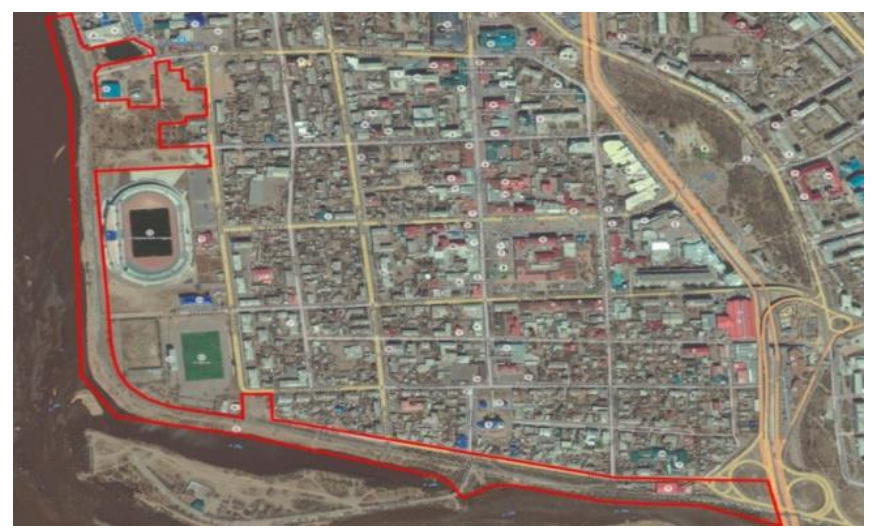

Fig. 1. Limits of the area allocated for elaboration of the design projects on accomplishment of the embankment of the rivers Uda and Selenga in the city of Ulan-Ude [3]. 

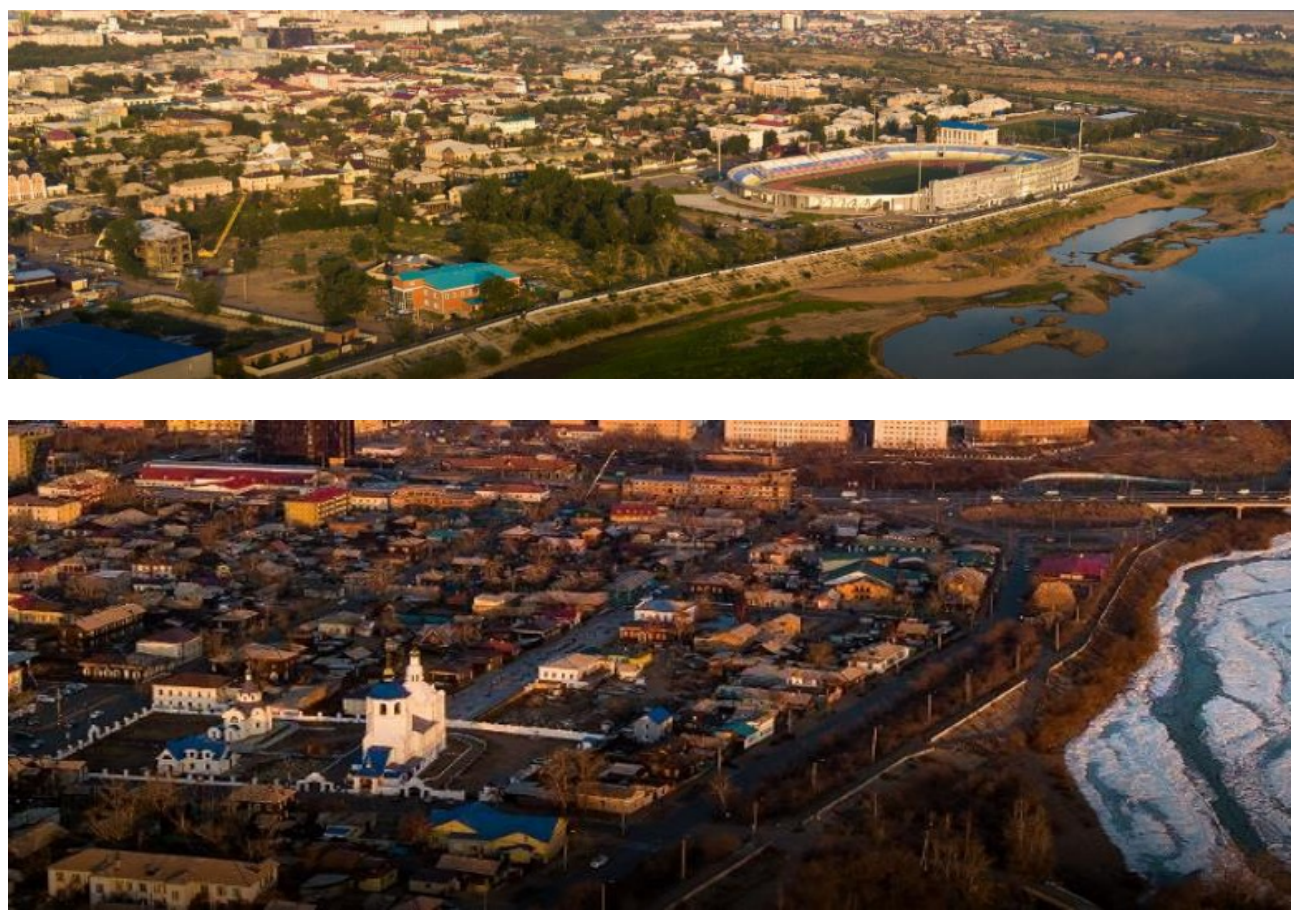

Fig. 2 Existing states of the western and southern sides of the embankment of the rivers Uda and Selenga in the city of Ulan-Ude.

Figures 3, 4, and 5 display the most successful ideas of the design projects that have participated in the vote for the best one.

Complex development of territories and spatial planning is a rule of the contemporary land development in the situation of the built-up areas. It should work irrespective of size of the plot of land, whether it is 0.06 hectares or 100 hectares. This rule is based on the principle of functional zoning of the land plot that means division of it into its useful parts and its development by formation of the infrastructure suitable for living and future use.

As the analysis has shown, none of the presented projects of reconstruction of the embankment applies to the principle of the complex development of territories. It is connected with the fact that the specification includes the embankment only, without surrounding territory that leads to impossibility of development of any plots of land proposed for the competition. This area has economic and spatial contradictions, which mean, on the one hand, a successful location in proximity to the city center, favorable geographic position in the place of confluence of the two rivers. On another hand, this is a territory with high social tension connected with slums in the surrounding space, and as a consequence, with high criminality. It is impossible to make "an island of prosperity" amidst the devastation.

The authors have analyzed the projects presented for the competition that reached the final, through the prism of possibility of implementing these projects. 


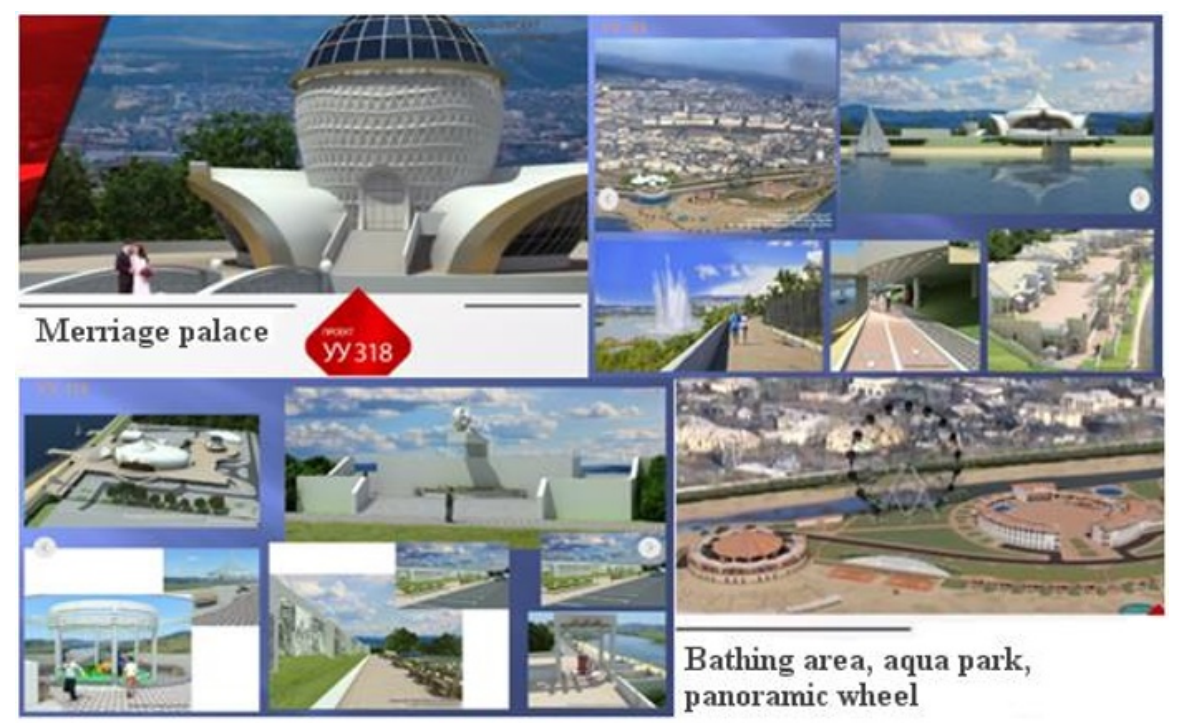

Fig. 3. The project UU318 - one of the nominees presented for vote to the residents of the city [5].

In general, the presented projects correspond to all requirements. In each of them, the proposals forming the modern comfort urban environment have been formulated, and the options for exploitation of the plots of land as socially important objects have been effectively considered. However, it is necessary to point out that only one project of the three considers functional zoning of the territory from the point of view of its operation and benefit in the future, while rest of the projects are mostly of socio-esthetic character.

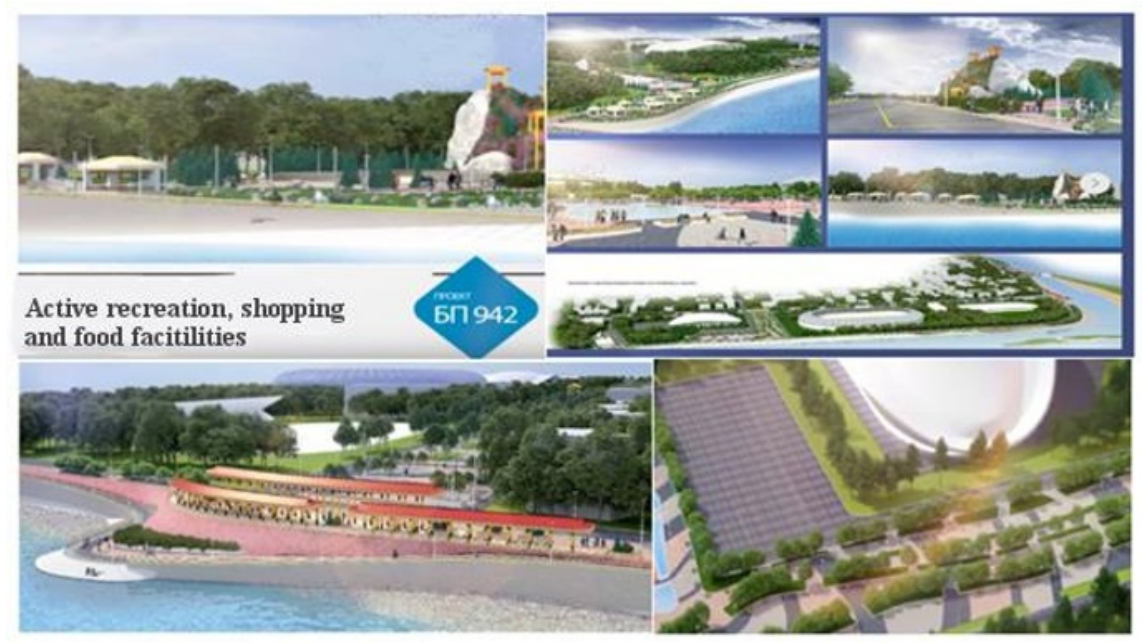

Fig. 4. Project BP 942 - one of the nominees presented for vote to the residents of the city [5]. 


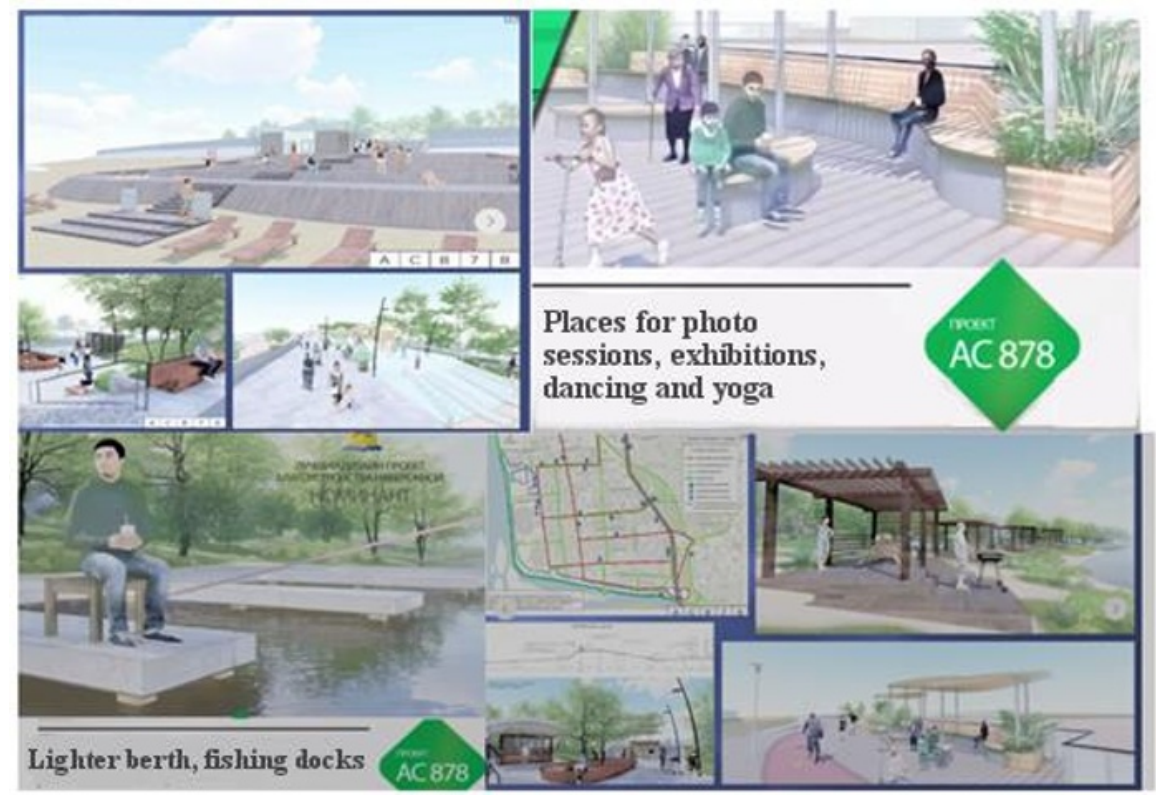

Fig. 5 Project AC 878 - one of the nominees presented for vote to the residents of the city [4].

Based on the example of the area allocated for the accomplishment of the embankment of the rivers Uda and Selenga in the city of Ulan-Ude, let us consider the option of the spatial zoning.

The authors suggest zoning of this territory with outlining the following parts:

- Cultural zone;

- Commercial zone;

- Parklands;

- Beach area;

- Infrastructure.

Cultural zone - according to the specification compiled by the Administration of the city of Ulan-Ude, it is announced that a cultural zone for arranging exhibitions, festivals, competitions, etc. should be allocated. The cultural zone should also include a building for the theater of the ensemble "Baikal", Wedding Palace, spectator amphitheater setting screen for broadcast events, summer cinema, and organization of singing and dancing fountains in the river. High commercial benefit has not been envisaged for this zone but it should be selfsufficient.

Commercial zone provides for the creation of trading platforms for lease, the income from which will be directed to repay the operating and management costs throughout the territory of improvement. This is a zone of the maximum commercial profit.

Parklands should include all elements of the landscape design, making green areas and placement of viewing platforms, the use of modern small architectural forms. It should also include provision of the Wedding Palace with thematic areas under the open sky. The parkland is to have engineering infrastructure for the normal life of the plants and trees. The length of the Parklands should be stretched as much as possible throughout the territory for hiking, cycling, sports programs, the "green trail" route, and organization of healthimproving paths. It is desirable to have small sports facilities, taking into account the seasonality to be used year-round. This zone is not intended for high commercial income but should be self-sufficient. 
Beach area is a part of the territory which should have a direct and civilized assess to the water. The beach area includes primarily cleaning and preparation of the river bottom for the organization of beaches, construction of mini-water parks, and preparation of the coastline. In addition, cabins for changing clothes and for showers, storage of property, rescue towers, and trained personnel are welcome. The beach area requires special attention in financial terms, i.e. the cost of maintenance and management of the area can be compensated through autonomous use with a differentiated framework of responsibility.

Infrastructure is focused on support and provision of the major conditions of life of basic and low-mobility groups, security functions, maintenance of law and order, and safety of the population (video surveillance, patrol, installation of panic buttons, vandal-proof security cabins, etc.). In addition to that, it is desirable to provide for the possibility of transport communications (roads and their entrances, bicycle paths, etc.), parking spaces and parking lots, etc. This zone envisages high commercial profitability.

Division of land under this scheme will allow containing less profitable plots at the expense of high-income, attracting private entrepreneurs to practically each zone and satisfying socio-esthetic demands of the population.

Speaking about development, it is necessary to touch the problem of the assessment of its effectiveness. As the Russian practice has shown, the effective investment decision that is by $20-50 \%$ higher the average on the market is only possible, when the market is thoroughly analyzed and the plot of land correctly selected. If one considers the effectiveness of the accepted decisions by the stages of the development project, correct decision at the stage of the preliminary justification will allow optimizing use of the investment means by $10-15 \%$. At the stage of registration of property rights and other legal issues, the value of land can grow by another $150-300 \%$. So, for example, transferring land from one category to another or changing the purpose of the land plot can increase the value of land by 100-200\%. Design and engineering, and technological development of the land increases its value by $150 \%$ in average [2]

Complex approach can be used for the assessment of effectiveness of development projects that allow considering different kinds of effectiveness for all participants of the project and for the interested parties [7]:

- Commercial effectiveness that allows evaluating projects from the perspective of the developer and investors;

- Economic effectiveness that allows assessing projects from the perspectives of its impact to the economic development as a whole;

- Budget effectiveness that allows assessing projects from the point of view of the budget interests.

As a whole, positive impact of development to the economy can be considered from the standpoint of territorial and branch development. Improvement of territories is conditioned by the fact that only the best development project leads to the qualitative changes of not only the objects of reals estates themselves but their environment that contribute to the growth of their value in a maximum way. One more time we would like to point out that maximization of the positive impact of development on the quality of territorial development can only be achieved by the complex approach that allow developing real estate objects in complex with other objects considering the problem of development of the adjacent territory.

If we touch the problem of effectiveness of development from the perspective of the branch development, it is evident that investments into real estates will lead to the growth of activity in the related industries, such as production of the construction materials, housing and communal services, production of consumer durable goods, etc.

The budget effectiveness of development is manifested in the increase of payments and taxes that appear in the process of implementation of development projects and functioning 
of the built real estate objects (payments for the right to build, lease payments for the land, taxes and revenue of developers and investors, taxes on wages of employees, engaged in the implementation of the projects, income taxes of the enterprises, property taxes, land tax, etc. as well as savings in connection with the increase of employment of the population, growth of their incomes, etc.) $[4,6]$.

Since the result of development is a creation of the real estate objects satisfying certain demands of business and population, it is needed to consider social effectiveness of development. It manifests itself in improving quality of the environment and life activity, incomes, and quality of life of the population under the changes in the fund of housing.

Therefore, the effectiveness of development is determined by the increase of the market value of land, profitability of real estate objects located on this area, increase of the income component of the state budget and increasing level of wellbeing of population on that territory.

Without solution of economic and spatial contradictions of surrounding territory, its development and redevelopment, all represented projects have a format of "a project for the sake of the project". Development of the adjacent built-up territories for the implementation of the project of reconstruction of the embankment taking into account complex planning will provide for solution of the following tasks:

- The issue of slums;

- Equal distribution of the functional zones;

- Provision with the transport accessibility;

- Forming modern public and business space in the center of the city;

- The growth of value of the real estate objects;

- Solving social issues related to the provision of population with comfort conditions of life.

If all these properly considered, the presented projects can be implemented with subsequent positive impact for the city and its residents and guests.

\section{References}

1. E. B. Golovanov, V. A. Kiseleva, O. N. Larin, Modern Problems of Science and Education, 2 (2012)

2. I. I. Mazur, V. D. Shapiro, Development of real estate under the general editorship (Omega-L, Moscow, 2010)

3. The official site of the Committee for Architecture and Urban Planning in Ulan-Ude, terms of reference for order number $17 r$ dated January 12, 2013 (http://ulan-udeeg.ru/industry/gradostr-politika/konkurs-naberejnoi/sndt2a06_copy. pdf, 2013)

4. A. V. Bogoviz, S. V. Lobova, A. N. Alekseev, I. A. Koryagina, T. V. Aleksashina, Advances in Intelligent Systems and Computing, 622, 609-616 (2018)

5. Official site of the Republic of Buryatia, the project "Embankment of the rivers Uda and Selenga" (http://buryatia.site/riverside, 2018)

6. Y. V. Ragulina, A. V. Bogoviz, A. N. Alekseev, Advances in Intelligent Systems and Computing, 622, 568-573 (2018)

7. D. Frick, H. W. Hoefert, H. Legewie, R. Mackensen, R. K. Silbereisen, Quality of urban life: social, psychological, and physical conditions (De Gruyter, Berlin, 1986) 